UDK $577.1: 61$

ISSN 1452-8258

J Med Biochem 39: 40-45, 2020

\title{
EFFECTS OF AN EIGHT-WEEK EXERCISE PROGRAM ON PARAMETERS OF THE LIPID PROFILE OF FEMALE STUDENTS
}

\author{
EFEKTI OSMONEDELJNOG PROGRAMA VEŽBANJA NA LIPIDNI PROFIL STUDENTKINJA
}

\author{
Irina Juhas ${ }^{1}$, Branko Skof ${ }^{2}$, Dejana Popović3, Milan Matić1, Nenad Janković \\ ${ }^{1}$ University of Belgrade, Faculty of Sport and Physical Education, Belgrade, Serbia \\ ${ }^{2}$ University of Ljubljana, Faculty of Sport, Ljubljana, Slovenia \\ ${ }^{3}$ Clinical Center of Serbia, University of Belgrade, Faculty of Pharmacy
}

\begin{abstract}
Summary
Background: Increased lipid levels are one of the major risk factors for the development of cardiovascular diseases. The aim of the current study was to evaluate the effect of shortterm ( 8 weeks) aerobic exercise of moderate to vigorous intensity on lipid profile in young healthy females.

Methods: 27 female students (mean age $20.5 \pm 1$ year) completed 8 weeks of aerobic training that included two exercise sessions of continuous aerobic activity of moderate intensity (running 35-60 $\mathrm{min}$ ) and one exercise session with interval training of vigorous intensity. Intervention aerobic capacity and lipid profile were examined before and after the exercise.

Results: Exercise intervention has caused a decrease of low density lipoprotein levels per 9.8\% (from $2.52 \pm 0.47$ to $2.27 \pm 0.53 \mathrm{mmol} / \mathrm{L} ; \mathrm{p}<0.001$ ) and significant improvement of high density lipoprotein (HDL) levels per 22.7\% (from $1.29 \pm 0.24$ to $1.59 \pm 0.24 \mathrm{mmol} / \mathrm{L} ; \mathrm{p}<0.001$ ), total cholesterol/HDL ratio per $17.2 \%$ and aerobic capacity $\left(\mathrm{VO}_{2}\right.$ max $)$ per $3.8 \%(43.9 \pm 3.7$ to $45.56 \pm 3.63$ $\mathrm{mLO}_{2} / \mathrm{kg} / \mathrm{min}$ ).

Conclusions: The results support the hypothesis that a short-term aerobic exercise intervention of moderate to vigorous intensity may have significant effects on blood lipid profile in young healthy females.
\end{abstract}

Keywords: lipid profile, female, aerobic training

\section{Kratak sadržaj}

Uvod: Povećani nivo lipida je jedan od značajnih faktora rizika za razvoj kardiovaskularnih bolesti. Cilj ovog istraživanja je da se procene efekti kratkog ( 8 nedelja) aerobnog vežbanja, umerenog do visokog intenziteta, na lipidni profil.

Metode: 27 studentkinja (prosečne starosti 20,5 \pm 1 godina) je izloženo osmonedeljnom aerobnom vežbanju koje se sastojalo od treninga kontinuirane aerobne aktivnosti umerenog intenziteta (trčanje 35-60 min) dva puta nedeljno i intervalnog treninga visokog intenziteta jednom nedeljno. Lipidni profil je određen pre i posle programa vežbanja.

Rezultati: Program vežbanja je doveo do smanjenja nivoa

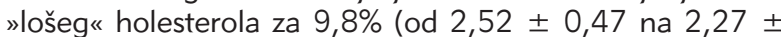
$0,53 \mathrm{mmol} / \mathrm{L} ; \mathrm{p}<0,001)$, značajnog povećanja »dobrog « holesterola (HDL) za 22,7\% (od 1,29 \pm 0,24 na 1,59 \pm $0,24 \mathrm{mmol} / \mathrm{L} ; \mathrm{p}<0,001)$, odnosa ukupnog holesterola/HDL za 17,2\% i poboljšanja aerobnog kapaciteta $\left(\mathrm{VO}_{2}\right.$ max $)$ za $3,8 \%$ (od 43,9 $\pm 3,7$ na 45,56 $\pm 3,63$ $\mathrm{mLO}_{2} / \mathrm{kg} / \mathrm{min}$ ).

Zaključak: Rezultati istraživanja podržavaju hipotezu da kratkotrajno aerobno vežbanje od umerenog do visokog intenziteta ima značajan uticaj na lipidni profil mladih, zdravih, ženskih osoba.

Ključne reči: lipidni profil, žene, aerobno vežbanje

\footnotetext{
Address for correspondence:

Irina Juhas

Faculty of Sport and Physical Education

156 Blagoja Parovica Street, 11030 Belgrade

Phone +381 $113531031 ;$ Fax + 381113531100

e-mail: irina.juhas@fsfv.bg.ac.rs
}

List of abbreviations: TC, Total Cholesterol; HDL, High-Density Lipoprotein; LDL, Low-Density Lipoprotein; TG, Triglycerides; $\mathrm{VO}_{2}$ max, maximal oxygen uptake. 


\section{Introduction}

Hypercholesterolemia is an important risk factor for the development of atherosclerosis, ischemic heart disease and stroke $(1,2)$. According to the American Heart Association, 54\% of adult Europeans aged $>25$ suffer from increased cholesterol levels higher than $5.17 \mathrm{mmol} / \mathrm{L}$ (3). Decreasing of LowDensity Lipoprotein (LDL) levels over a lifetime for 1 $\mathrm{mmol} / \mathrm{L}$ is associated with a $55 \%$ lower risk for cardiovascular diseases (4).

Among different forms of physical activity, the authors have highlighted the importance of aerobic exercise. Special training programs can have a significant impact on improving the quality of life of individuals or their skills. Walking and running are the cyclical activities most used to develop aerobic fitness, which is important physical ability for health. Developing interest in a healthy population for this form of physical activity is important in order to include it in their everyday life as an integral component of a healthy lifestyle.

Regular physical activity has a number of positive effects on blood lipids profile (5-7). Cross-sectional studies have clearly shown that well-trained endurance athletes (runners, cyclists, and triathletes) have lower triglycerides (TG) (19-50\%) and LDL (7$21 \%)$ levels and higher High-Density Lipoprotein (HDL) levels (5-59\%) in comparison with untrained individuals (8). Current exercise guidelines recommend 150 minutes/week of moderate intensity exercise or 75 minutes/week of vigorous intensity exercise on most or at least five days per week for the improvement of health parameters $(6,9-12)$.

Studies have shown that the exercise threshold for the effects on lipid profile is between 1200-2200 $\mathrm{kcal} /$ week and that the volume and intensity of exercise are positively correlated with the beneficial effects on lipid profile $(8,13)$, as HDL will increase $0.008 \mathrm{mmol} / \mathrm{L}$ per each kilometre of the running distance (14). The response of the specific lipid profile components to exercise is different. HDL and TG are much more sensitive to the exercise-related changes than are LDL and total cholesterol (TC), as only $25 \%$ of the studies have shown that exercise will induce some changes in the LDL and TC levels $(8,13)$.

Although there is a general agreement that exercise is beneficial for the improvement of lipid profile, it is still not known in terms of exercise intensity what is the most beneficial exercise regimen, volume, and duration of the exercise intervention. In the past few years, high-intensity interval training (HIIT) has become very popular as important for health effects on lipid profile $(15,16)$.

The main purpose of this study was to evaluate the effects of 8-week moderate to vigorous aerobic exercise on the lipid profile in young healthy females, with a wish to investigate the preventive effects of aerobic exercise.

\section{Materials and Methods}

\section{Participants}

The research was conducted on a sample of 27 female students (mean age $20.5 \pm 1$ year; body mass $60.1 \pm 5.5 \mathrm{~kg}$, body height $168.1 \pm 6.2 \mathrm{~cm}$ ) in the second year of undergraduate studies at the Faculty of Sport and Physical Education, the University of Belgrade, whose instruction syllabus already contain the 8-week training program of preparation for crosscountry running. All the subjects were healthy and had no neurological, orthopaedic, cardiovascular and metabolic disorders, nor were using medications that could influence research results. Participants entered the study after being informed about the purpose, potential benefits, and possible risks of the training program. They were also required to sign an informed consent document.

The study protocol was approved by the Ethics Committee of the Faculty of Sport and Physical Education, University of Belgrade.

\section{Study design}

Exercise intervention that was used in the study was created as a training program for students to apply one of the methods for developing aerobic endurance and to prepare students for the $4000 \mathrm{~m}$ cross-country race. Participants were also instructed to maintain their normal diet (17) and daily activities throughout the duration of the study. There was no nutritional intervention during the study. Before and after the exercise intervention, all participants underwent the anthropometric and body composition testing and shuttle run test. Blood samples for full lipid profile were also taken before and after the exercise intervention.

\section{Exercise intervention}

Based on the results of initial measurements, an individual program was created, which was subsequently implemented by each student. The individual training program was structured in two ways: based on the running velocity realized at the initial shuttle run measurement and based on the value of heart rate (by determining maximum heart rate). The exercise lasting 45-60 minutes was performed 3 times a week, and it included 10 minutes' warm-up followed by a main running session that included three exercise zones. Zone 1 was long a slow distance run lasting 45 minutes at $60-80 \%$ of the maximal heart rate (6-7 MET). Zone 2 training was 35-45 minutes run at $81-90 \% \mathrm{HR}_{\max }(8-10 \mathrm{MET})$, and zone 3 included interval runs: $2 \times 1600 \mathrm{~m}$ or $2 \times 2400 \mathrm{~m}$ race pace at 91-100\% HR $\max (11-15 \mathrm{MET})(18,19,20)$. Each participant wore a Suunto dual belt HR monitor during the process to control the intensity of training. 


\section{Measurements}

\section{Shuttle run test}

In order to assess the aerobic capacity $\left(\mathrm{VO}_{2 \max }\right)$, the multistage progressive 20-meter "shuttle run « test was used. This test was performed on a hard synthetic surface located in an indoor sports arena. Subjects ran between two lines $20 \mathrm{~m}$ apart in time with a sound signal which was emitted from an audio cassette. The frequency of the sound signals increased every minute. The test was terminated when the subject was no longer able to follow the set pace and did not reach the targeted line on three consecutive occasions. The level attained and the number of shuttles at that level allowed a prediction of $\mathrm{VO}_{2 \text { max }}$ as suggested by Ramsbottom et al. (21).

\section{Blood samples}

To monitor the exercise effects on the lipid profile, the following variables were selected: TC $(\mathrm{mmol} / \mathrm{L})$, $\mathrm{HDL}(\mathrm{mmol} / \mathrm{L}), \mathrm{TC} / \mathrm{HDL}$ ratio, $\mathrm{LDL}(\mathrm{mmol} / \mathrm{L})$ and plasma TG concentration $(\mathrm{mmol} / \mathrm{L})$. Blood samples were taken between 7 and 8 a.m. to avoid variations in circadian rhythm. A complete blood count was determined on the haematology cell counter Coulter LH750 (Beckman Coulter, Inc., Fullerton, CA). Total cholesterol, $\mathrm{HDL}, \mathrm{LDL}$ and $\mathrm{TG}$ were routinely determined by automatic analyzer BT 2000 (Biotehnica, Milan, Italy) using automated methods and bioMérieux (Marcy I'Etoile, France) reagents.

\section{Statistical analysis}

Mean and standard deviation were used to report basic descriptive parameters. The differences between the initial and final tests were analyzed using the Student's t-test for paired samples. The impact of training on the calculated variables was determined using ETA squared test. The normal distribution of the results was examined by the Shapiro-Wilk test. The extreme points were established by a boxplot. It was found that there were no extreme points in the used variables. All data were analyzed using SPSS software (20.0, SPSS, Chicago, IL). A significance level of .05 was used for all tests.

\section{Results}

The effect of exercise intervention on aerobic capacity

Mean values of shuttle run tests, velocity and duration, and $\mathrm{VO}_{2}$ max in the initial and final measurements are shown in Table I.
Table I Mean values of velocity and duration of shuttle run and $\mathrm{VO}_{2}$ max in the initial and final measurements.

\begin{tabular}{|c|c|c|c|c|c|}
\hline Variables & & M & SD & $\mathrm{p}$ & ETA \\
\hline \multirow{2}{*}{$\begin{array}{l}\text { Shuttle run - } \\
\text { velocity }(\mathrm{m} / \mathrm{s})\end{array}$} & In & 11.68 & 0.61 & \multirow{2}{*}{0.007} & \multirow{2}{*}{0.24} \\
\hline & Fin & 11.96 & 0.62 & & \\
\hline \multirow{2}{*}{$\begin{array}{l}\text { Shuttle run - } \\
\text { duration (min) }\end{array}$} & $\ln$ & $6: 49$ & $1: 12$ & \multirow{2}{*}{0.001} & \multirow{2}{*}{0.36} \\
\hline & Fin & $7: 22$ & $1: 12$ & & \\
\hline \multirow{2}{*}{$\begin{array}{l}\mathrm{VO}_{2} \max \\
\left(\mathrm{mLO}_{2} / \mathrm{kg} / \mathrm{min}\right)\end{array}$} & $\ln$ & 43.89 & 3.66 & \multirow{2}{*}{0.001} & \multirow{2}{*}{0.36} \\
\hline & Fin & 45.56 & 3.63 & & \\
\hline
\end{tabular}

$\mathrm{VO}_{2}$ max - maximal oxygen uptake; In - Initial measurement; Fin - Final measurement

ETA - Eta-squared; 0.01 low impact; 0.06 medium impact; 0.14 high impact

Values of ETA squared test higher than 0.14 examined dependent variables confirm that the impact of training programs on health parameters of the test is significant.

The initial measurement of $\mathrm{VO}_{2 \max }$ was $43.9 \pm$ $3.7 \mathrm{~mL} \mathrm{O} / \mathrm{kg} / \mathrm{min}$ and the final measurement 45.56 $\pm 3.63 \mathrm{~mL} \mathrm{O} / 2 / \mathrm{kg} / \mathrm{min}$, which represents a significant increase $(p<0.001)$ between the initial and final measurements in the amount of $1.67 \mathrm{~mL} \mathrm{O} / \mathrm{kg} / \mathrm{min}$ (3.8\%). Overall, there was an $8 \%$ increment in the shuttle run performance and running velocity $(p<$ $0.01)$. These values are expected as the training program was based predominantly on the type of endurance training (22).

The effects of exercise intervention on blood lipid profile

Mean values of the TC, HDL, LDL, and TG in the initial and final measurements are shown in Table II.

Table II Parameters of lipid status at the initial and final phase of measurements.

\begin{tabular}{|l|c|c|c|c|c|}
\hline & & Mean & SD & P & ETA \\
\hline TC $(\mathrm{mmol} / \mathrm{L})$ & $\ln$ & 4.12 & .62 & 0.278 & 0.04 \\
\hline & Fin & 4.19 & .59 & & \\
\hline $\mathrm{HDL}(\mathrm{mmol} / \mathrm{L})$ & $\ln$ & 1.29 & .24 & 0.000 & 0.83 \\
\hline & Fin & 1.59 & .24 & & \\
\hline $\mathrm{TC} / \mathrm{HDL}(\%)$ & $\ln$ & 3.25 & 0.52 & 0.000 & 0.80 \\
\hline & Fin & 2.68 & 0.46 & & \\
\hline $\mathrm{LDL}(\mathrm{mmol} / \mathrm{L})$ & $\ln$ & 2.52 & .47 & 0.000 & 0.38 \\
\hline & Fin & 2.27 & .53 & & \\
\hline TG (mmol/L) & $\ln$ & .619 & .219 & 0.009 & 0.23 \\
\hline & Fin & .717 & .223 & & \\
\hline
\end{tabular}

$\mathrm{TC}=$ Total cholesterol, $\mathrm{HDL}=$ High Density Lipoprotein, $\mathrm{LDL}=$ Low Density Lipoprotein, TG = triglycerides

$\mathrm{VO}_{2}$ max - maximal oxygen uptake; In - Initial measurement; Fin - Final measurement 
The average TC did not change after the exercise intervention $(p<0.05)$. However, survey results show that components of the lipid profile were improved. HDL increased from 1.29 to $1.59 \mathrm{mmol} / \mathrm{L}$, ( $p<0.001)$, and LDL decreased from 2.52 to 2.27 $\mathrm{mmol} / \mathrm{L},(p<0.001)$. There was also a significant improvement of the TC/HDL ratio ( $p<0.001)$, while the TG level has increased ( $p<0.01)$.

\section{Discussion}

There were various exercising programs presented in scientific studies to examine the effect of physical exercises on lipid status in healthy population through exercising programs of different duration ranging from 20 days to 24 months $(8,13)$. In our research, the selected program of aerobic exercises was established as a model running program for the preparation of physically active adults which lasted long enough to improve aerobic endurance.

The main finding of the present study is that 8 weeks of mainly aerobic activity of moderate to vigorous intensity caused significant improvements in blood lipid profile and aerobic capacity in young healthy females. The most important significant changes were (1) improvement of $\mathrm{VO}_{2 \max }$ and the increase in endurance measured through shuttle run test (2), the increase in HDL levels, with concomitant improvement of $\mathrm{TH} / \mathrm{HDL}$ levels, and (3) the decrease of LDL levels. We have also registered a significant increase in TG levels.

The energy consumption of an exercise intervention was estimated to be between 800-1040 $\mathrm{kcal} /$ week and was of sufficient intensity to improve aerobic capacity and running endurance. In the current investigation, certain improvement of the running endurance was expected in the study subjects, while that was otherwise physically active population and the study protocol was their first experience with the structured aerobic endurance exercise program. There are probably two possible explanations for this outcome. First of all, it is likely that the improvement of the running endurance was related to the functional and biochemical adaptations that could be best noticed through the significant improvements of $\mathrm{VO}_{2 \text { max }}$ levels. Secondly, we believe that there were also some neuromuscular adaptations related to the running economy and better functioning of the stretch-shortening cycle that is important in the running. The $3.8 \%$ improvement of $\mathrm{VO}_{2 \max }$ was relatively large and comparable only to the results reported in well-trained female athletes (23). In such trained athletes we could expect progress at the intensities higher than used in our study (e.g., 95\% HR $\mathrm{R}_{\text {max }}$ ) (24). The results from the studies investigating the effects of aerobic training on untrained females show much greater improvements in the range of 10 to $20 \%$ (25). However, our participants belonged to the regularly physically active population (although not trained athletes) and their $\mathrm{VO}_{2 \max }$ levels were relatively high even at the beginning of the study which might explain fewer improvements than expected. It is also possible that a short period of exercise intervention (8 weeks instead of the usual 12 weeks) could have been the additional explanation of such an outcome.

The results have also shown a specific response of lipid profile to aerobic exercise intervention. The increase of HDL levels was above the mean values of $4.6 \%$ as reported in the meta-analysis of the effects of aerobic exercise on cholesterol and lipid profile (13). The findings are consistent with the known fact that aerobic activity of moderate intensity (like as a long slow distance running 45-60 min at about 70\% HR max in our study) targets HDL levels. The observed reduction in LDL in our study could be explained through the HDL accelerated removal of LDL and by the direct impact of vigorous and high vigorous exercise (high-intensity interval runs) on lowering LDL also. It was reported before that the lowering of LDL, as well as TG levels, requires greater exercise intensity and longer duration of exercise intervention (more than 8 weeks) (13). Furthermore, even the rise of TG levels could in part support the fact that exercise intensity is related to the specific changes of lipid profile. This was also noticed in the study that investigated the effect of aerobic exercise at different intensity, on TG levels where TG levels have raised for $12 \%$ in a group with moderate intensity exercise (26). In contrast to that, the same study has reported that in a group with high-intensity interval training TG levels have decreased by $50 \%$. To sum up, our study supports the previous findings that exercise intensity is related to the specificity of lipid profile changes in response to exercise. Moderate intensity exercise will increase HDL levels, while high-intensity exercise will additionally decrease LDL and TG levels. This could have an important implication for the creation of exercise programs in recreational sport and individuals with overweight, obesity and dyslipidemia problems. These persons usually poorly tolerate high-intensity exercises and the exercise protocol used in our study could be a good starting alternative for them to gain aerobic capacity and prepare themselves for highintensity exercise later on.

The increase of HDL levels is related to the volume of aerobic exercise. Cross-sectional studies have shown that the threshold for this effect (the increase of HDL per $0.05-0.08 \mathrm{mmol} / \mathrm{L}$ ) is around 1200 and $2200 \mathrm{kcal} /$ week which is in line with current guidelines (10-12) about the health-enhancing levels of physical activities for healthy adults. However, estimated energy consumption in our study was only 800-1200 $\mathrm{kcal} /$ week or $18 \mathrm{~km}$ of running/week $(3 \times 300-400$ $\mathrm{kcal} /$ exercise session) and it was still enough to cause significant improvements of HDL levels that are in line with other studies $(27,28,15)$ that reported the even short-term vigorous-intensity exercise could have beneficial health effects on lipid profile. 


\section{Limitations}

Initial physical activity readiness bias may be one of the study limitations. As such, the results of the current study should be evaluated in larger clinical trials.

\section{Conclusions}

The current study reveals that even short-term (8 weeks) moderate to vigorous intensity aerobic exercise at low energy consumption (around 1000 $\mathrm{kcal} /$ week) has a beneficial effect on the lipid profile and aerobic capacity at young adult healthy females.

\section{References}

1. Lloyd-Jones DM, Wilson PW, Larson MG, Beiser A, Leip $E P, D^{\prime}$ Agostino RB, et al. Framingham risk score and prediction of lifetime risk for coronary heart disease. Am J Cardiol 2004; 94(1): 20-4.

2. Milošević Georgiev A, Krajinović D, Kotur-Stevuljević J, Ignjatović S, Marinković V. Undiagnosed hyperglycaemia and hypertension as indicators of the various risk factors of future cardiovascular disease among population of Serbian students. J Med Biochem 2018; 37: 289-98.

3. Roger VL, Go AS, Lloyd-Jones DM, Benjamin EJ, Berry $J D$, Borden WB, et al. Heart disease and stroke statistics - 2012 update: a report from the American Heart Association. Circulation 2012; 125(1): e2-220.

4. Ference BA, Yoo, W, Alesh, I, Mahajan N, Mirowska KK, Mewada $A$, et al. Effect of long-term exposure to lower low-density lipoprotein cholesterol beginning early in life on the risk of coronary heart disease: a Mendelian randomization analysis. J Am Coll Cardiol 2012; 60(25): 2631-9.

5. ACSM (American College of Sports Medicine). Position stand: The recommended quantity and quality of exercise for developing and maintaining cardiorespiratory and muscular fitness and flexibility in healthy adults; Med Sci Sports Exerc 1998; 30(6): 975-91.

6. Garber CE, Blissmer B, Deschenes M R, Franklin BA, Lamonte MJ, Lee IM, et al. American College of Sports Medicine position stand. Quantity and quality of exercise for developing and maintaining cardiorespiratory, musculoskeletal, and neuromotor fitness in apparently healthy adults: guidance for prescribing exercise. Med Sci Sports Exerc 2011; 43(7): 1334-59.

7. Aadahl M, Kjaer M, Jørgensen T. Associations between overall physical activity level and cardiovascular risk factors in an adult population. Eur J Epidemiol 2007; 22(6): 369-78.

8. Durstine JL, Grandjean PW, Davis PG, Ferguson MA, Alderson NL, DuBose KD. Blood Lipid and Lipoprotein Adaptations to Exercise. Sports Med 2001; 31(15): 1033-62.
Acknowledgements. The paper is part of the project »Effects of applied physical activity on locomotion, metabolic, psycho-social and educational status of the population in the Republic of Serbia « number III47015, as a part of subproject »Effects of applied physical activity on locomotion, metabolic, psychosocial and educational status of the student population in the Republic of Serbia « which is financed by Ministry of Education and Science of the Republic of Serbia.

\section{Conflict of interest statement}

The authors stated that they have no conflicts of interest regarding the publication of this article.

9. Kostrzewa-Nowak D, Buryta R, Nowak R. T cell subsets' distribution in elite karate athletes as a response to Physical Effort. J Med Biochem 2019; 38: 342-52.

10. Garvey WT, Mechanick JI, Brett EM, Garber AJ, Hurley $\mathrm{DL}$, Jastreboff $\mathrm{AM}$, et al. Reviewers of the CE/ACE Obesity Clinical Practice Guidelines. American Association of Clinical Endocrinologists and American College of Endocrinology comprehensive clinical practice guidelines for medical care of patients with obesity: executive summary. Endocr Pract 2016; 22(7): 842-84.

11. Lobelo F, Rohm Young D, Sallis R, Garber MD, Billinger SA, Duperly J, et al. American Heart Association Physical Activity Committee of the Council on Lifestyle and Cardiometabolic Health; Council on Epidemiology and Prevention; Council on Clinical Cardiology; Council on Genomic and Precision Medicine; Council on Cardiovascular Surgery and Anesthesia; and Stroke Council. Routine Assessment and Promotion of Physical Activity in Healthcare Settings: A Scientific Statement from the American Heart Association. Circulation 2018; 137(18): e495-e522.

12. Ponikowski P, Voors AA, Anker SD, Bueno H, Cleland JG, Coats AJ, et al. 2016 ESC Guidelines for the diagnosis and treatment of acute and chronic heart failure: The Task Force for the diagnosis and treatment of acute and chronic heart failure of the European Society of Cardiology (ESC). Developed with the special contribution of the Heart Failure Association (HFA) of the ESC. Eur J Heart Fail 2016; 18(8): 891-975.

13. Mann S, Beedie C, \& Jimenez A. Differential Effects of Aerobic Exercise, Resistance Training and Combined Exercise Modalities on Cholesterol and the Lipid Profile: Review, Synthesis and Recommendations. Sports Med 2014; 44: 211-21.

14. Kokkinos P, Holland J, Narayan P, Colleran JA, Dotson $\mathrm{CO}$, Papademetriou $\mathrm{V}$, et al. Miles run per week and highdensity lipoprotein cholesterol levels in healthy middleaged men: a dose-response relationship. Arch Intern Med 1995; 155: 415-20. 
15. Nybo L, Sundstrup E, Jakobsen M, Mohr M, Hornstrup T, Simonsen $L$, et al. High-intensity training versus traditional exercise interventions for promoting health. Med Sci Sports Exerc 2010; 42(10): 1951-58.

16. Tjonna AE, Leinan IM, Bartnes AT, Jenssen BM, Gibala MJ, Winett RA, et al. Low- and high-volume of intensive endurance training significantly improves maximal oxygen uptake after 10-weeks of training in healthy men, PloS One, 2013; 8(5): e65382.

17. O'Donovan G, Owen A, Bird S, Kearney EM, Nevill AM, Jones DW, et al. Changes in cardiorespiratory fitness and coronary heart disease risk factors following 24 wk of moderate- or high-intensity exercise of equal energy cost. J Appl Physiol 2005; 98(5): 1619-25.

18. Wen CP, Wai JP, Tsai MK, Yang YC, Cheng TY, Lee MC, et al. Minimum amount of physical activity for reduced mortality and extended life expectancy: a prospective cohort study. The Lancet 2011; 378(9798): 1244-53.

19. Munoz I, Seiler KS, Bautista J, Espana J, Larumbe E, Esteve-Lenao J. Does Polarized Training Improve Performance in Recreational Runners. Int J Sports Physiol and Perform 2014; 9: 265-72.

20. Seiler KS, Kjerland GO. Quantifying training intensity distribution in endurance athletes: is there evidence for an »optimal« distribution? Scand J Med Sci Sports 2006; 16(1): 49-56.

21. Ramsbottom R, Brewer J, Williams C. A progressive shuttle run test to estimate maximal oxygen uptake. $\mathrm{Br} \mathrm{J}$ Sports Med 1988; 22: 141-45.
22. Gormley S, Swain D, High R, Spina R, Dowling E, Kotipalli $U$, et al. Effect of intensity of aerobic training on $\mathrm{VO}_{2 \max }$. Med Sci Sports Exerc 2008; 40(7): 1336-43.

23. Auersperger I, Knap B, Jerin A, Blagus $R$, Lainščak $M$, Skitek $M$, et al. The effects of 8 weeks of endurance running on hepcidin concentrations, inflammatory parameters and iron status in female runners. Int J Sport Nutr Exerc Metab 2012; 22(1): 55-63.

24. Helgerud J, Hoydal K, Wang E, Karlsen T, Berg P, Bjerkaas M. Aerobic high-intensity intervals improve VO2max more than moderate training. Med Sci Sports Exerc 2007; 39(4): 665-71.

25. Schubert MM, Washburn RA, Honas JJ, Lee J, Donnelly JE. Exercise volume and aerobic fitness in young adults: the Midwest Exercise Trial-2. SpringerPlus 2016; 5: 183-91.

26. Elmer DJ, Laird RH, Barberio MD, Pascoe DD. Inflammatory, lipid, and body composition responses to interval training or moderate aerobic training. Eur J Appl Physiol 2016; 116(3): 601-9.

27. LeMura L, von Duvillard S, Andreacci J, Klebez JM, Chelland JM, Russo J, et al. Lipid and lipoprotein profiles, cardiovascular fitness, body composition, and diet during and after resistance, aerobic and combination training in young women. Eur J Appl Physiol 2000; 82(5-6): 451-8.

28. Banz W, Maher M, Thompson W, Bassett DR, Moore W, Ashraf $M$, et al. Effects of resistance versus aerobic training on coronary artery disease risk factors. Exp Biol Med (Maywood), 2003; 228(4): 434-40.

Received: December 12, 2018

Accepted: January 30, 2019 